\title{
THE GEOMORPHOSITES ASSESSMENT FOR DETERMINATING THE GEOTOURISM POTENTIAL. CASE STUDY ON THE NATURAL PARK PUTNA-VRANCEA ROMANIA
}

DOI: http://dx.doi.org/10.18509/GBP.2020.56

UDC: 338.48-6:551.1/.4]:303.83(498-751.2)"2014/2020"

\author{
Ionuț Tufănoiu ${ }^{1,2}$ \\ Alina Simion ${ }^{1,2}$ \\ Arina Mărunțelu1,2 \\ Bogdan Teriș \\ Alexandra Grecu ${ }^{1,2}$ \\ ${ }^{1}$ University of Bucharest, Faculty of Geography, Romania \\ ${ }^{2}$ University of Bucharest - Research Center for \\ Integrated Analysis and Territorial Management (CAIMT), Romania
}

\begin{abstract}
Globally, geotourism is a segment of the tourism market that has experienced one of the fastest growths in recent years and it is expected that this rapid growth will continue in the future. In this context, the protection, conservation and exploitation of geomorphosites become important objectives from the perspective of developing sustainable tourism. From this perspective, the evaluation of geomorphosites is an important element in terms of their tourism promotion. This helps us not only to determine their scientific value but also other additional values.

In this study, we performed an evaluation of the geomorphosites within the PutnaVrancea Natural Park, Romania using assessment methods and criterias recognized by international standards. The purpose of this study is to highlight the real geotouristic potential of the area. The studied area represents a protected area of national interest in Romania, which corresponds to the 5th category (Natural Park) according to the IUCN (International Union for Conservation of Nature) classification with a diverse landscape potential, which requires an evaluation of the geomorphosites in order to raise awareness of its geotouristic value.

The results of this evaluation will be a basis for rethinking the protection and conservation of the geomorphosites and promoting geotourism activities at local and regional level.
\end{abstract}

Keywords: geotourism, geomorphosites, criterias, evaluation methods, tourism.

\section{INTRODUCTION}

One of the newest concepts in the field of tourism, the geotourism, focuses on promoting the geological and geomorphological features of the landscape as tourist attractions [1]. Even though tourism and geology are two different fields of study, they can coexist and can be synthesized in geotourism [2]. The first definition of geotourism belongs to T.A. Hose, who considers geotourism as "a way of promoting, preserving and understanding the geological heritage, the tourist exceeding the stage of the simple aesthetic appreciation of the landscape" [3]. This new part of the tourism market is based on the conservation of geotourism and geodiversity through a sustainable policy and management, but at the same time, the geotourism is a broad concept that includes more tourist activities, from transport and accommodation, to recreational activities. In addition, beyond the economic 
value of geotourism, this activity also has educational purposes, thus informing tourists on how the environment works, as well as the need to conserve the geotourism heritage [4], [5], [6], [7].

Recently introduced as an acronym for "geomorphological site", the term "geomorphosite" [8] can be understood as a landform that has acquired a special value due to human perception or exploitation [9]. This value may vary depending on the orientation: scientific, ecological, cultural, aesthetic and/or economic [10]. According to the narrow definition of the term, a geomorphosite can be any part of the Earth's surface important for understanding the Earth, climate or life history [10], [11]. Geomorphosites can be single geomorphological objects or large landscapes and can be affected, modified or even destroyed by human activities [12].

Most of the studies in the field have focused on the geomorphosites assessment. So far, several methods have been developed and applied for evaluating geomorphosites, of which, among the most important are: the method of evaluating the tourist value of geomorphosites given by the Geography Institute of the University of Laussane introduced by J.P. Pralong in 2005 [13] and developed by E. Reynard et al. in 2007 [14]; the method proposed at the University of Cantabria in 2005 by V.M. Bruschi and A. Cendrero [15]; the method developed by the University of Modena and Reggio Emilia team in 2005 by P. Coratza and C. Giusti [16]; the method developed at the University of Valladolid in 2005 by E. Serrano and J.J. Gonzalez Trueba [17]; the method given by the University of Minho in 2005 by P. Pereira and developed in 2007 [18]; the Greek method proposed by N. Zourous in 2007 [19]; the Slavonic method appeared in 2010 by B. Erhatic [20] and the Romanian method presented by L. Comănescu et al. in 2011 [21].

The evaluation of geomorphosites aims to establish their value from several points of view. Any assessment of geomorphosites must answer three basic questions: "What?", "Why?" and "How?" [11]. Thus, the first question refers to the establishment of the inventory of geomorphosites that must be evaluated, the second question follows the objectives for which the evaluation must be performed and the last question relates to the evaluation method that must be used.

The evaluation of geomorphosites has the final aim, in most of cases, the tourism promotion, but it can also be used for scientific, educational or ecological purposes.

\section{METHODOLOGY}

\section{The study area}

The studied area is represented by the Putna-Vrancea Natural Park, a protected area of national interest with a diverse geomorphological and landscape potential, which covers a total area of approximately $382 \mathrm{~km} 2$, in the northwestern part of the Vrancea county, occupying $41 \%$ of the mountain area of the county. (Fig.1). The study area overlaps most of the mountain hydrographic basin of the Putna river to which the Mordanu and Goru massifs are added in the southwestern part [22].

From a geological point of view, as part of the Vrancea Mountains, the Putna-Vrancea Natural Park is the result of the alpine orogenesis and belongs to the flysch deposits. The geological composition stands out through a great petrographic and structural heterogeneity, an aspect that in collaboration with the positive or negative tectonic movements recorded over time has resulted in a complex relief that favors the existence of spectacular landscapes [22]. 


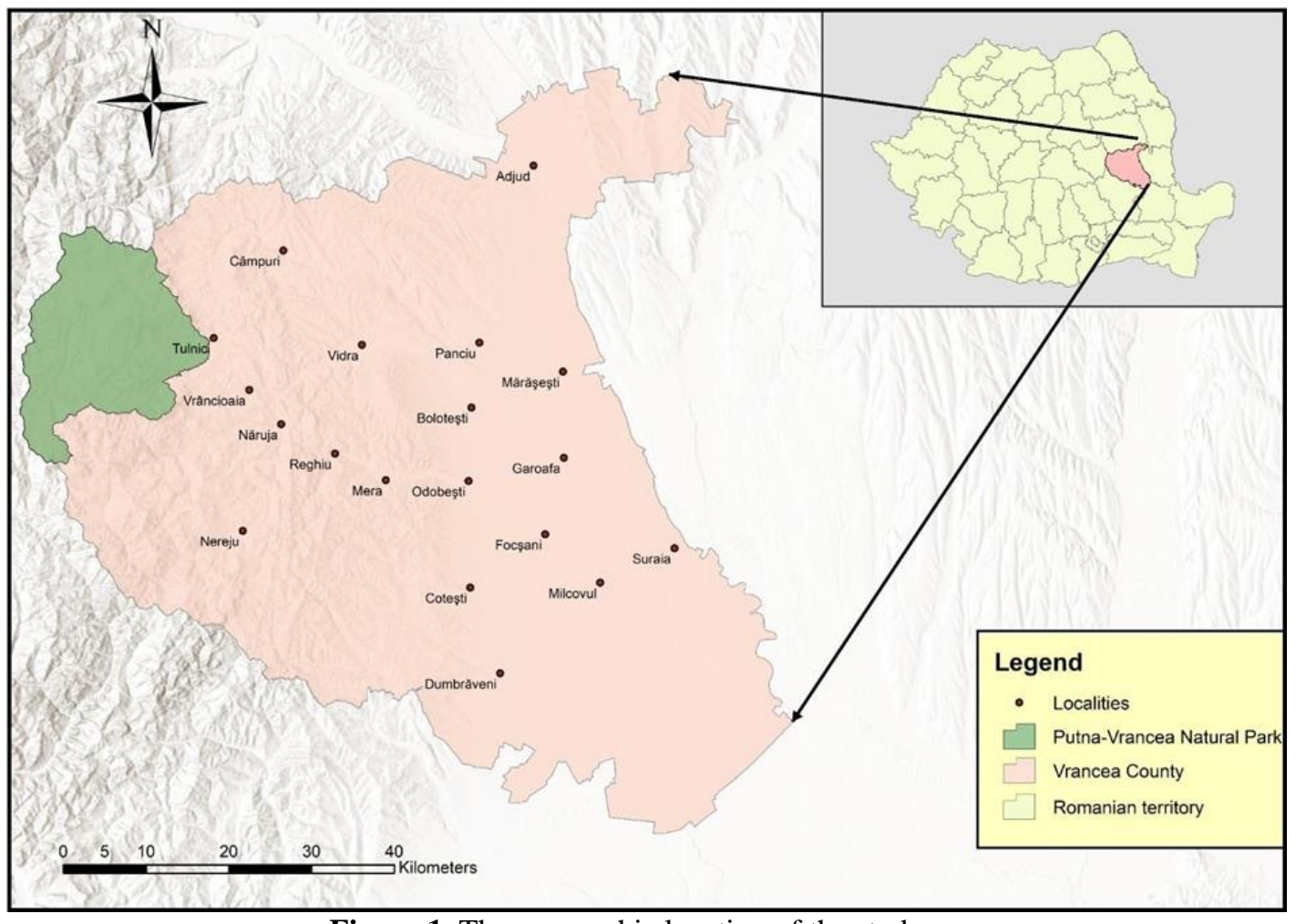

Figure 1. The geographic location of the study area

\section{Data}

The objective of the present study is to generate a method for evaluating the geomorphosites that will match the best the characteristics of the analyzed area in order to highlight the geotourism potential.

Starting from the already existing and internationally proven evaluation methodologies, the present study aims to carry out an evaluation of the geomorphosites, which focuses on both the classical values of the geomorphosites (scientific, aesthetic, ecological, cultural), as well as on the aspects which concerns the possible tourist utility of the geomorphosites or their degree of integrity.

Thus, as a first step, the literature of the field was studied, the available cartographic materials were consulted and important data from the field was collected.

The next step was to identify and select the geomorphosites for evaluation. This step has been done by consulting the satellite images, the topographic map, but especially on the field (field trips).

Once the geomorphosites for evaluation have been identified, a database that contains the most important attributes of the geomorphosites were created. This will be extremely useful in the assessment of geomorphosites, but also for the development of future cartographic materials.

The evaluation was done done according to the criteria presented in Table 1. 
Table 1. The criteria proposed for the evaluation of the geomorphosites (Source: Comănescu et al. 2011, with modifications and additions by the authors)

\begin{tabular}{|c|c|c|c|c|c|c|c|c|c|}
\hline \multicolumn{2}{|c|}{ Scientific value } & \multicolumn{2}{|c|}{ Economic value } & \multicolumn{2}{|c|}{ Aesthetic value } & \multicolumn{2}{|c|}{ Cultural value } & \multicolumn{2}{|c|}{$\begin{array}{l}\text { Management and } \\
\text { use value }\end{array}$} \\
\hline PTS & 25 & PTS & 20 & PTS & 20 & PTS & 20 & PTS & 15 \\
\hline $1,5-$ & $\begin{array}{l}\text { rareness at } \\
\text { national level }\end{array}$ & $4-$ & $\begin{array}{l}\text { infrastructur } \\
\mathrm{e}\end{array}$ & $4-$ & visibility & $4-$ & $\begin{array}{l}\text { symbolic } \\
\text { value }\end{array}$ & $3-$ & $\begin{array}{l}\text { preservation } \\
\text { degree }\end{array}$ \\
\hline $1,5-$ & $\begin{array}{l}\text { rareness in } \\
\text { relation to the } \\
\text { area }\end{array}$ & $4-$ & accessibility & $4-$ & $\begin{array}{l}\text { color } \\
\text { contrast }\end{array}$ & $4-$ & $\begin{array}{l}\text { cultural } \\
\text { characteristi } \\
\text { cs }\end{array}$ & $3-$ & $\begin{array}{l}\text { the intensity } \\
\text { of use }\end{array}$ \\
\hline $3-$ & $\begin{array}{l}\text { degree of } \\
\text { scientific } \\
\text { knowledge on } \\
\text { geomorpholog } \\
\text { ical issues }\end{array}$ & $4-$ & $\begin{array}{l}\text { number of } \\
\text { types and } \\
\text { forms of use } \\
\text { (inclusively } \\
\text { touristic) }\end{array}$ & 4 - & $\begin{array}{l}\text { level } \\
\text { difference }\end{array}$ & $2-$ & $\begin{array}{l}\text { iconographic } \\
\text { /literary } \\
\text { representatio } \\
\text { ns }\end{array}$ & $3-$ & $\begin{array}{l}\text { the use of } \\
\text { aesthetic, } \\
\text { cultural and } \\
\text { economic } \\
\text { value }\end{array}$ \\
\hline $3-$ & $\begin{array}{l}\text { paleogeograph } \\
\text { ic interest }\end{array}$ & $4-$ & $\begin{array}{l}\text { yearly } \\
\text { visitors } \\
\text { number }\end{array}$ & $4-$ & $\begin{array}{l}\text { landscape } \\
\text { framing }\end{array}$ & $4-$ & $\begin{array}{l}\text { religious } \\
\text { characteristi } \\
\text { cs }\end{array}$ & 2 - & $\begin{array}{l}\text { vulnerabil } \\
\text { ity/natural } \\
\text { risks }\end{array}$ \\
\hline $3-$ & $\begin{array}{l}\text { integrity/intact } \\
\text { ness }\end{array}$ & $4-$ & $\begin{array}{l}\text { economic } \\
\text { potential } \\
\text { (incomes) }\end{array}$ & $4-$ & $\begin{array}{l}\text { space } \\
\text { structurin } \\
\mathrm{g}\end{array}$ & $4-$ & $\begin{array}{l}\text { historical } \\
\text { characteristi } \\
\text { cs }\end{array}$ & $2-$ & $\begin{array}{l}\text { relationship } \\
\text { with planning } \\
\text { policies }\end{array}$ \\
\hline 3 - & $\begin{array}{l}\text { use in } \\
\text { educational } \\
\text { purposes }\end{array}$ & & & & & & $\begin{array}{l}\text { cultural } \\
\text { manifestatio } \\
\text { ns }\end{array}$ & $2-$ & $\begin{array}{l}\text { equipment } \\
\text { and support } \\
\text { services }\end{array}$ \\
\hline $2-$ & diversity & & & & & & & & \\
\hline $5-$ & ecologic value & & & & & & & & \\
\hline $2-$ & $\begin{array}{l}\text { representative } \\
\text { ness }\end{array}$ & & & & & & & & \\
\hline $1-$ & $\begin{array}{l}\text { other } \\
\text { geological } \\
\text { features }\end{array}$ & & & & & & & & \\
\hline
\end{tabular}

The total value of each geomorphosite was calculated as following:

$\mathrm{Vtot}=\mathrm{Vs}+\mathrm{Ve}+\mathrm{Va}+\mathrm{Vc}+\mathrm{Vmu} / 100$

Vtot - total value of the geomorphosite

Vs - scientific value

$\mathrm{Ve}$ - economic value

$\mathrm{Va}$ - aesthetic value

Vc - cultural value

$\mathrm{Vmu}$ - management and use value
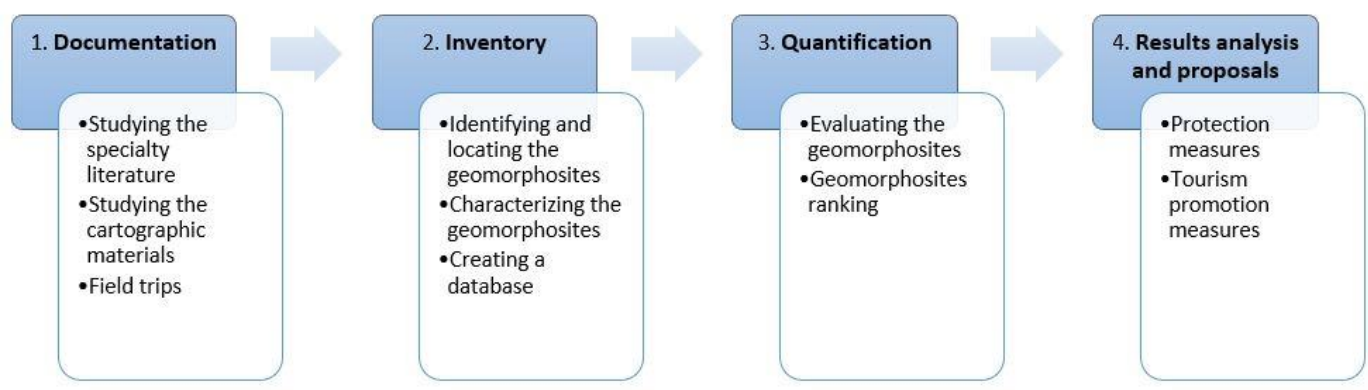

Figure 2. The stages of studying geomorphosites

The evaluation involves the distribution of 100 points (absolute maximum) between the 5 criteria (scientific value, economic value, aesthetic value, cultural value and management and use value) with their sub-criteria. The total points accumulated by each geomorphosite following the application of the criteria was divided to 100 , so that the 
final value of the evaluated geomorphosite was between 0 (the minimum value) and 1 (the maximum value).

The results obtained by each geomorphosite were classified so that the values obtained for each criteria can be compared separately. These can be extremely useful in the event of improving protection measures, but also for tourism promotion.

GIS software was used to produce the mapping materials (Arc Map 10.3).

\section{RESULTS}

There were selected for evaluation a number of 8 geomorphosites from the Putna-Vrancea Natural Park (Table 2, Fig. 3).

Table 2. The geomorphosites selected for the evaluation

\begin{tabular}{ccc}
\hline Nr. & Name & Type \\
\hline $\mathbf{1 .}$ & Cheile Tișiței & areal \\
$\mathbf{2 .}$ & Cascada Putnei & areal \\
$\mathbf{3 .}$ & Groapa cu Pini & areal \\
\hline $\mathbf{4 .}$ & Strâmtura Coza & areal \\
\hline $\mathbf{5 .}$ & Cascada din Horn & punctual \\
\hline $\mathbf{6 .}$ & Varful Goru & punctual \\
\hline $\mathbf{7 .}$ & Vârful Lăcăuți & punctual \\
\hline $\mathbf{8 .}$ & Râpa Roșie & areal \\
\hline
\end{tabular}

"Cheile Tișiței" represents a sector of gorges shaped by the waters of the Tișiţa River between the Tisaru Mare Peak and Măgura Râpa Caprei, that is in the lower course of the Tișiţa valley. This area also has the quality of protected area, being classified in the category of mixed nature reserves (hydrogeomorphological, forestry, floristic and landscape type) according to law no. 5/2000. The spectacularity of the area is imposed by the tectonic and hydro-erosional fragmentation correlated with the local geology. The alternation of deep and narrow valleys with depression basins give a canyon appearance, the width of the gorges alternating between $3 \mathrm{~m}$ and $10 \mathrm{~m}$.

The waterfall "Cascada Putnei" is also a protected area of national interest and corresponds to the 4th category of IUCN, having the status of natural reserve of geological and landscape type.

The geological and landscape reserve "Cascada Putnei" is located at a distance of $3 \mathrm{~km}$ from Lepșa and represents an area in which the river Putna crosses the outer border of Vrancea Mountains on a fault line where it creates the current waterfall. In the downstream of the current waterfall, at about $200 \mathrm{~m}$ away, on the left shore of Putna, there is an old waterfall that became inactive due to the geotectonic movements that caused a portion of the old riverbed to go down and thus it made Putna change its course to the right, forming the current riverbed, this phenomenon being unique in Romania.

This waterfall has a spectacular character due to the riverbed, which presents some features resulting from the selective action of the water (the selective modeling of rocks) and the tectonization of the geological formations. The water flows rapidly from one marmite (circular hollows formed by erosion in the riverbed) to another, calming only at the bottom of the waterfall where a deep basin is formed [23].

The waterfall is about $76 \mathrm{~m}$ long, it has an average flow of $9 \mathrm{~m}^{3} / \mathrm{s}$ and a level difference around $14 \mathrm{~m}$. 


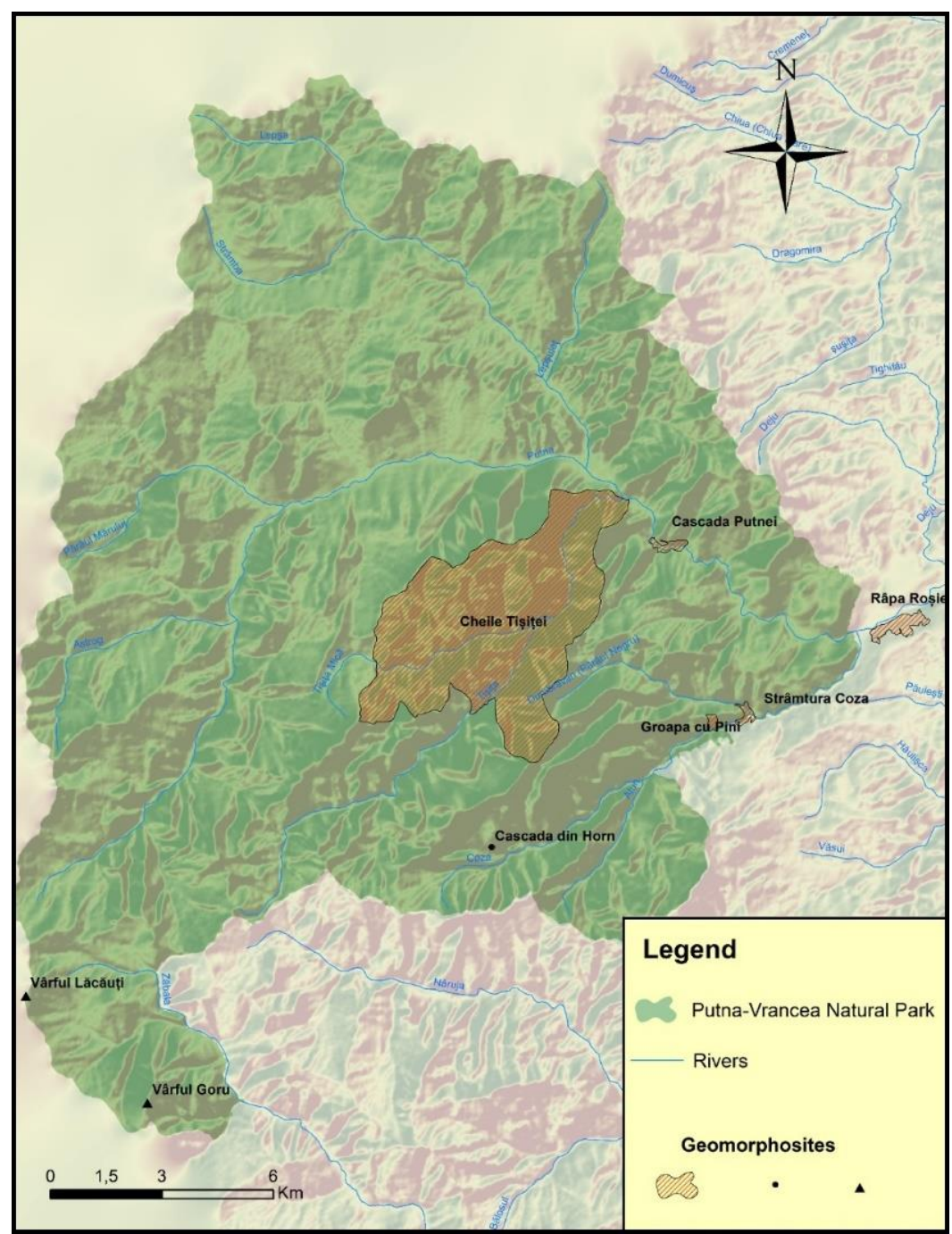

Figure 3. The location of the analized geomorphosites

"Groapa cu Pini" is another protected area in Putna-Vrancea Natural Park. The reservation is located on the left side of a sector of the upper course of the Coza River and is home to geological structures with important paleontological and landscape elements. The reservation is noticeable by the yellow-gray-reddish colors and the lower and upper Tisaru layers that show marks of fossil fauna.

"Stramtura Coza" is a complex geomorphosite located also in an sector of the Coza River, downstream of Groapa cu Pini. This is a geomorphological and landscape type reservation, evidenced mainly by the faulted structure of the layers, which, in corroboration with the surface erosion, results in successions of beautifully colored soil layers that make up a spectacular landscape.

"Cascada din Horn" or "Cascada Mioarele", as it is also called by the locals, is a waterfall of about $25 \mathrm{~m}$ high located on an affluent of the Coza River. The waterfall is located in a picturesque place and stands out through the fact that the water does not touch the rocky wall.

The peaks of Lăcăuți and Goru represent the highest peaks in the Putna-Vrancea Natural Park (1776.7 m, respectively $1784.6 \mathrm{~m}$ ) and at the same time some very good viewpoints. Placed on the northwest-southeast direction, the Lăcăuți-Goru Mountains are made of hard sandstone and correspond to a maximum elevation axis from the Carpathian Curves. 
In addition, Goru Peak is included in the nature reserve of Mount Goru, which occupies the western slope of the massif [22].

Table 3. The evaluation of the geomorphosite nr. 1

\begin{tabular}{|c|c|c|c|c|c|c|c|c|c|}
\hline \multicolumn{2}{|c|}{ Scientific value } & \multicolumn{2}{|c|}{ Economic value } & \multicolumn{2}{|c|}{ Aesthetic value } & \multicolumn{2}{|c|}{ Cultural value } & \multicolumn{2}{|c|}{$\begin{array}{c}\text { Management and } \\
\text { use value }\end{array}$} \\
\hline PTS & 25 & PTS & 20 & PTS & 20 & PTS & 20 & PTS & 15 \\
\hline 1 - & $\begin{array}{l}\text { rareness at } \\
\text { national level }\end{array}$ & $2-$ & $\begin{array}{l}\text { infrastructur } \\
\mathrm{e}\end{array}$ & $4-$ & visibility & $2-$ & $\begin{array}{l}\text { symbolic } \\
\text { value }\end{array}$ & $2,5-$ & $\begin{array}{l}\text { preservation } \\
\text { degree }\end{array}$ \\
\hline $1,5-$ & $\begin{array}{l}\text { rareness in } \\
\text { relation to the } \\
\text { area }\end{array}$ & $3-$ & accessibility & $4-$ & $\begin{array}{l}\text { color } \\
\text { contrast }\end{array}$ & $4-$ & $\begin{array}{l}\text { cultural } \\
\text { characteristi } \\
\text { cs }\end{array}$ & $2-$ & $\begin{array}{l}\text { the intensity } \\
\text { of use }\end{array}$ \\
\hline 3 - & $\begin{array}{l}\text { degree of } \\
\text { scientific } \\
\text { knowledge on } \\
\text { geomorpholog } \\
\text { ical issues }\end{array}$ & $2-$ & $\begin{array}{l}\text { number of } \\
\text { types and } \\
\text { forms of use } \\
\text { (inclusively } \\
\text { touristic) }\end{array}$ & $3-$ & $\begin{array}{l}\text { level } \\
\text { difference }\end{array}$ & $0,5-$ & $\begin{array}{l}\text { iconographic } \\
\text { /literary } \\
\text { representatio } \\
\text { ns }\end{array}$ & $2-$ & $\begin{array}{l}\text { the use of } \\
\text { aesthetic, } \\
\text { cultural and } \\
\text { economic } \\
\text { value }\end{array}$ \\
\hline 3 - & $\begin{array}{l}\text { paleogeograph } \\
\text { ic interest }\end{array}$ & $2-$ & $\begin{array}{l}\text { yearly } \\
\text { visitors } \\
\text { number }\end{array}$ & $3-$ & $\begin{array}{l}\text { landscape } \\
\text { framing }\end{array}$ & $2-$ & $\begin{array}{l}\text { religious } \\
\text { characteristi } \\
\text { cs }\end{array}$ & $1,5-$ & $\begin{array}{l}\text { vulnerabil } \\
\text { ity/natural } \\
\text { risks }\end{array}$ \\
\hline $2,5-$ & $\begin{array}{l}\text { integrity/intact } \\
\text { ness }\end{array}$ & $2-$ & $\begin{array}{l}\text { economic } \\
\text { potential } \\
\text { (incomes) }\end{array}$ & $3-$ & $\begin{array}{l}\text { space } \\
\text { structurin } \\
\mathrm{g}\end{array}$ & $2-$ & $\begin{array}{l}\text { historical } \\
\text { characteristi } \\
\text { cs }\end{array}$ & $1-$ & $\begin{array}{l}\text { relationship } \\
\text { with planning } \\
\text { policies }\end{array}$ \\
\hline 2 - & $\begin{array}{l}\text { use in } \\
\text { educational } \\
\text { purposes }\end{array}$ & & & & & $0,5-$ & $\begin{array}{l}\text { cultural } \\
\text { manifestatio } \\
\text { ns }\end{array}$ & $1-$ & $\begin{array}{l}\text { equipment } \\
\text { and support } \\
\text { services }\end{array}$ \\
\hline $2-$ & diversity & & & & & & & & \\
\hline $5-$ & ecologic value & & & & & & & & \\
\hline $2-$ & $\begin{array}{l}\text { representative } \\
\text { ness }\end{array}$ & & & & & & & & \\
\hline \multirow[t]{4}{*}{1 - } & $\begin{array}{l}\text { other } \\
\text { geological } \\
\text { features }\end{array}$ & & & & & & & & \\
\hline & 23 & & 11 & & 17 & & 11 & & 10 \\
\hline & & & & & $72 \mathrm{pts}$ & & & & \\
\hline & & & Total value: & & 0.72 & & & & \\
\hline
\end{tabular}

Located on a sector of the right slope of the Putna River downstream from the confluence with the Coza River, "Râpa Roșie" is a geomorphological type reserve with a relief characterized by steep slopes and weakly cohesive deposits that were strongly fragmented by the hydro-erosional processes. Thus, the relief of the reservation is dominated by forms such as canyons, towers or funnels, which give the landscape a pseudocarastic appearance, very spectacular.

Table 4. The evaluation of the geomorphosite nr. 2

\begin{tabular}{|c|c|c|c|c|c|c|c|c|c|}
\hline \multicolumn{2}{|c|}{ Scientific value } & \multicolumn{2}{|c|}{ Economic value } & \multicolumn{2}{|c|}{ Aesthetic value } & \multicolumn{2}{|c|}{ Cultural value } & \multicolumn{2}{|c|}{$\begin{array}{c}\text { Management and } \\
\text { use value }\end{array}$} \\
\hline PTS & 25 & PTS & 20 & PTS & 20 & PTS & 20 & PTS & 15 \\
\hline $1,5-$ & $\begin{array}{l}\text { rareness at } \\
\text { national level }\end{array}$ & $3-$ & $\begin{array}{l}\text { infrastructur } \\
\mathrm{e}\end{array}$ & $4-$ & visibility & $3-$ & $\begin{array}{l}\text { symbolic } \\
\text { value }\end{array}$ & $2,5-$ & $\begin{array}{l}\text { preservation } \\
\text { degree }\end{array}$ \\
\hline $1,5-$ & $\begin{array}{l}\text { rareness in } \\
\text { relation to the } \\
\text { area }\end{array}$ & $4-$ & accessibility & $4-$ & $\begin{array}{l}\text { color } \\
\text { contrast }\end{array}$ & $4-$ & $\begin{array}{l}\text { cultural } \\
\text { characteristi } \\
\text { cs }\end{array}$ & $2,5-$ & $\begin{array}{l}\text { the intensity } \\
\text { of use }\end{array}$ \\
\hline 3 - & $\begin{array}{l}\text { degree of } \\
\text { scientific } \\
\text { knowledge on } \\
\text { geomorpholog } \\
\text { ical issues }\end{array}$ & $2-$ & $\begin{array}{l}\text { number of } \\
\text { types and } \\
\text { forms of use } \\
\text { (inclusively } \\
\text { touristic) }\end{array}$ & $4-$ & $\begin{array}{l}\text { level } \\
\text { difference }\end{array}$ & $0,5-$ & $\begin{array}{l}\text { iconographic } \\
\text { /literary } \\
\text { representatio } \\
\text { ns }\end{array}$ & $2,5-$ & $\begin{array}{l}\text { the use of } \\
\text { aesthetic, } \\
\text { cultural and } \\
\text { economic } \\
\text { value }\end{array}$ \\
\hline 3 - & $\begin{array}{l}\text { paleogeograph } \\
\text { ic interest }\end{array}$ & $3-$ & $\begin{array}{l}\text { yearly } \\
\text { visitors } \\
\text { number }\end{array}$ & $2-$ & $\begin{array}{l}\text { landscape } \\
\text { framing }\end{array}$ & $2-$ & $\begin{array}{l}\text { religious } \\
\text { characteristi } \\
\text { cs }\end{array}$ & $1-$ & $\begin{array}{l}\text { vulnerabil } \\
\text { ity/natural } \\
\text { risks }\end{array}$ \\
\hline
\end{tabular}




\begin{tabular}{|c|c|c|c|c|c|c|c|c|c|}
\hline $2,5-$ & $\begin{array}{l}\text { integrity/intact } \\
\text { ness }\end{array}$ & $3-$ & $\begin{array}{l}\text { economic } \\
\text { potential } \\
\text { (incomes) }\end{array}$ & $2-$ & $\begin{array}{l}\text { space } \\
\text { structurin } \\
\mathrm{g}\end{array}$ & $2-$ & $\begin{array}{l}\text { historical } \\
\text { characteristi } \\
\text { cs }\end{array}$ & $1-$ & $\begin{array}{l}\text { relationship } \\
\text { with planning } \\
\text { policies }\end{array}$ \\
\hline 3 - & $\begin{array}{l}\text { use in } \\
\text { educational } \\
\text { purposes }\end{array}$ & & & & & $0,5-$ & $\begin{array}{l}\text { cultural } \\
\text { manifestatio } \\
\text { ns }\end{array}$ & $1,5-$ & $\begin{array}{l}\text { equipment } \\
\text { and support } \\
\text { services }\end{array}$ \\
\hline $1,5-$ & diversity & & & & & & & & \\
\hline $4-$ & ecologic value & & & & & & & & \\
\hline $2-$ & $\begin{array}{l}\text { representative } \\
\text { ness }\end{array}$ & & & & & & & & \\
\hline \multirow[t]{4}{*}{1 - } & $\begin{array}{l}\text { other } \\
\text { geological } \\
\text { features }\end{array}$ & & & & & & & & \\
\hline & 23 & & 15 & & 16 & & 12 & & 11 \\
\hline & & & & & $77 \mathrm{pts}$ & & & & \\
\hline & & & Total value: & & 0.77 & & & & \\
\hline
\end{tabular}

Table 5. The evaluation of the geomorphosite nr. 3

\begin{tabular}{|c|c|c|c|c|c|c|c|c|c|}
\hline \multicolumn{2}{|c|}{ Scientific value } & \multicolumn{2}{|c|}{ Economic value } & \multicolumn{2}{|c|}{ Aesthetic value } & \multicolumn{2}{|c|}{ Cultural value } & \multicolumn{2}{|c|}{$\begin{array}{c}\text { Management and } \\
\text { use value }\end{array}$} \\
\hline PTS & 25 & PTS & 20 & PTS & 20 & PTS & 20 & PTS & 15 \\
\hline 1- & $\begin{array}{l}\text { rareness at } \\
\text { national level }\end{array}$ & 1 - & $\begin{array}{l}\text { infrastructur } \\
\mathrm{e}\end{array}$ & $3-$ & visibility & $3-$ & $\begin{array}{l}\text { symbolic } \\
\text { value }\end{array}$ & $2,5-$ & $\begin{array}{l}\text { preservation } \\
\text { degree }\end{array}$ \\
\hline 1,5 - & $\begin{array}{l}\text { rareness in } \\
\text { relation to the } \\
\text { area }\end{array}$ & $2-$ & accessibility & $4-$ & $\begin{array}{l}\text { color } \\
\text { contrast }\end{array}$ & $4-$ & $\begin{array}{l}\text { cultural } \\
\text { characteristi } \\
\text { cs }\end{array}$ & $1-$ & $\begin{array}{l}\text { the intensity } \\
\text { of use }\end{array}$ \\
\hline $3-$ & $\begin{array}{l}\text { degree of } \\
\text { scientific } \\
\text { knowledge on } \\
\text { geomorpholog } \\
\text { ical issues }\end{array}$ & $1-$ & $\begin{array}{l}\text { number of } \\
\text { types and } \\
\text { forms of use } \\
\text { (inclusively } \\
\text { touristic) }\end{array}$ & $3-$ & $\begin{array}{l}\text { level } \\
\text { difference }\end{array}$ & $0,5-$ & $\begin{array}{l}\text { iconographic } \\
\text { /literary } \\
\text { representatio } \\
\text { ns }\end{array}$ & $1-$ & $\begin{array}{l}\text { the use of } \\
\text { aesthetic, } \\
\text { cultural and } \\
\text { economic } \\
\text { value }\end{array}$ \\
\hline $3-$ & $\begin{array}{l}\text { paleogeograph } \\
\text { ic interest }\end{array}$ & $1-$ & $\begin{array}{l}\text { yearly } \\
\text { visitors } \\
\text { number }\end{array}$ & $3-$ & $\begin{array}{l}\text { landscape } \\
\text { framing }\end{array}$ & $2-$ & $\begin{array}{l}\text { religious } \\
\text { characteristi } \\
\text { cs }\end{array}$ & $1,5-$ & $\begin{array}{l}\text { vulnerabil } \\
\text { ity/natural } \\
\text { risks }\end{array}$ \\
\hline $2,5-$ & $\begin{array}{l}\text { integrity/intact } \\
\text { ness }\end{array}$ & $1-$ & $\begin{array}{l}\text { economic } \\
\text { potential } \\
\text { (incomes) }\end{array}$ & $2-$ & $\begin{array}{l}\text { space } \\
\text { structurin } \\
\mathrm{g}\end{array}$ & $3-$ & $\begin{array}{l}\text { historical } \\
\text { characteristi } \\
\text { cs }\end{array}$ & $0,5-$ & $\begin{array}{l}\text { relationship } \\
\text { with planning } \\
\text { policies }\end{array}$ \\
\hline 2 - & $\begin{array}{l}\text { use in } \\
\text { educational } \\
\text { purposes }\end{array}$ & & & & & $0,5-$ & $\begin{array}{l}\text { cultural } \\
\text { manifestatio } \\
\text { ns }\end{array}$ & $0,5-$ & $\begin{array}{l}\text { equipment } \\
\text { and support } \\
\text { services }\end{array}$ \\
\hline $1,5-$ & diversity & & & & & & & & \\
\hline $4-$ & ecologic value & & & & & & & & \\
\hline $2-$ & $\begin{array}{l}\text { representative } \\
\text { ness }\end{array}$ & & & & & & & & \\
\hline 0,5 - & $\begin{array}{l}\text { other } \\
\text { geological } \\
\text { features }\end{array}$ & & & & & & & & \\
\hline & 21 & & 6 & & 15 & & 13 & & 7 \\
\hline & & & & & 62 pts & & & & \\
\hline & & & Total value: & & 0.62 & & & & \\
\hline
\end{tabular}

Table 6. The evaluation of the geomorphosite nr. 4

\begin{tabular}{|c|c|c|c|c|c|c|c|c|c|}
\hline \multicolumn{2}{|c|}{ Scientific value } & \multicolumn{2}{|c|}{ Economic value } & \multicolumn{2}{|c|}{ Aesthetic value } & \multicolumn{2}{|c|}{ Cultural value } & \multicolumn{2}{|c|}{$\begin{array}{c}\text { Management and } \\
\text { use value }\end{array}$} \\
\hline PTS & 25 & PTS & 20 & PTS & 20 & PTS & 20 & PTS & 15 \\
\hline $1,5-$ & $\begin{array}{l}\text { rareness at } \\
\text { national level }\end{array}$ & 1 - & $\begin{array}{l}\text { infrastructur } \\
\mathrm{e}\end{array}$ & $3-$ & visibility & $2-$ & $\begin{array}{l}\text { symbolic } \\
\text { value }\end{array}$ & $2,5-$ & $\begin{array}{l}\text { preservation } \\
\text { degree }\end{array}$ \\
\hline $1,5-$ & $\begin{array}{l}\text { rareness in } \\
\text { relation to the } \\
\text { area }\end{array}$ & $2-$ & accessibility & $4-$ & $\begin{array}{l}\text { color } \\
\text { contrast }\end{array}$ & $4-$ & $\begin{array}{l}\text { cultural } \\
\text { characteristi } \\
\text { cs }\end{array}$ & 1 - & $\begin{array}{l}\text { the intensity } \\
\text { of use }\end{array}$ \\
\hline 3 - & $\begin{array}{l}\text { degree of } \\
\text { scientific } \\
\text { knowledge on }\end{array}$ & $1-$ & $\begin{array}{l}\text { number of } \\
\text { types and } \\
\text { forms of use }\end{array}$ & $3-$ & $\begin{array}{l}\text { level } \\
\text { difference }\end{array}$ & $0,5-$ & $\begin{array}{l}\text { iconographic } \\
\text { /literary }\end{array}$ & $1-$ & $\begin{array}{l}\text { the use of } \\
\text { aesthetic, } \\
\text { cultural and }\end{array}$ \\
\hline
\end{tabular}




\begin{tabular}{|c|c|c|c|c|c|c|c|c|c|}
\hline & $\begin{array}{l}\text { geomorpholog } \\
\text { ical issues }\end{array}$ & & $\begin{array}{l}\text { (inclusively } \\
\text { touristic) }\end{array}$ & & & & $\begin{array}{l}\text { representatio } \\
\text { ns }\end{array}$ & & $\begin{array}{l}\text { economic } \\
\text { value }\end{array}$ \\
\hline 3 - & $\begin{array}{l}\text { paleogeograph } \\
\text { ic interest }\end{array}$ & $1-$ & $\begin{array}{l}\text { yearly } \\
\text { visitors } \\
\text { number }\end{array}$ & $3-$ & $\begin{array}{l}\text { landscape } \\
\text { framing }\end{array}$ & $2-$ & $\begin{array}{l}\text { religious } \\
\text { characteristi } \\
\text { cs }\end{array}$ & $1,5-$ & $\begin{array}{l}\text { vulnerabil } \\
\text { ity/natural } \\
\text { risks }\end{array}$ \\
\hline $2,5-$ & $\begin{array}{l}\text { integrity/intact } \\
\text { ness }\end{array}$ & $1-$ & $\begin{array}{l}\text { economic } \\
\text { potential } \\
\text { (incomes) }\end{array}$ & $2-$ & $\begin{array}{l}\text { space } \\
\text { structurin } \\
\mathrm{g}\end{array}$ & $2-$ & $\begin{array}{l}\text { historical } \\
\text { characteristi } \\
\text { cs }\end{array}$ & $0,5-$ & $\begin{array}{l}\text { relationship } \\
\text { with planning } \\
\text { policies }\end{array}$ \\
\hline $1,5-$ & $\begin{array}{l}\text { use in } \\
\text { educational } \\
\text { purposes }\end{array}$ & & & & & $0,5-$ & $\begin{array}{l}\text { cultural } \\
\text { manifestatio } \\
\text { ns }\end{array}$ & $0,5-$ & $\begin{array}{l}\text { equipment } \\
\text { and support } \\
\text { services }\end{array}$ \\
\hline $1,5-$ & diversity & & & & & & & & \\
\hline $2-$ & ecologic value & & & & & & & & \\
\hline 2 - & $\begin{array}{l}\text { representative } \\
\text { ness }\end{array}$ & & & & & & & & \\
\hline \multirow[t]{4}{*}{$0,5-$} & $\begin{array}{l}\text { other } \\
\text { geological } \\
\text { features }\end{array}$ & & & & & & & & \\
\hline & 19 & & 6 & & 15 & & 11 & & 7 \\
\hline & & & & & $58 \mathrm{pts}$ & & & & \\
\hline & & & Total value: & & 0.58 & & & & \\
\hline
\end{tabular}

Table 7. The evaluation of the geomorphosite nr. 5

\begin{tabular}{|c|c|c|c|c|c|c|c|c|c|}
\hline \multicolumn{2}{|c|}{ Scientific value } & \multicolumn{2}{|c|}{ Economic value } & \multicolumn{2}{|c|}{ Aesthetic value } & \multicolumn{2}{|c|}{ Cultural value } & \multicolumn{2}{|c|}{$\begin{array}{c}\text { Management and } \\
\text { use value }\end{array}$} \\
\hline PTS & 25 & PTS & 20 & PTS & 20 & PTS & 20 & PTS & 15 \\
\hline $0,5-$ & $\begin{array}{l}\text { rareness at } \\
\text { national level }\end{array}$ & $1-$ & $\begin{array}{l}\text { infrastructur } \\
\mathrm{e}\end{array}$ & $3-$ & visibility & $3-$ & $\begin{array}{l}\text { symbolic } \\
\text { value }\end{array}$ & $2-$ & $\begin{array}{l}\text { preservation } \\
\text { degree }\end{array}$ \\
\hline $1,5-$ & $\begin{array}{l}\text { rareness in } \\
\text { relation to the } \\
\text { area }\end{array}$ & $1-$ & accessibility & $4-$ & $\begin{array}{l}\text { color } \\
\text { contrast }\end{array}$ & $4-$ & $\begin{array}{l}\text { cultural } \\
\text { characteristi } \\
\text { cs }\end{array}$ & $1-$ & $\begin{array}{l}\text { the intensity } \\
\text { of use }\end{array}$ \\
\hline $2-$ & $\begin{array}{l}\text { degree of } \\
\text { scientific } \\
\text { knowledge on } \\
\text { geomorpholog } \\
\text { ical issues }\end{array}$ & $1-$ & $\begin{array}{l}\text { number of } \\
\text { types and } \\
\text { forms of use } \\
\text { (inclusively } \\
\text { touristic) }\end{array}$ & $4-$ & $\begin{array}{l}\text { level } \\
\text { difference }\end{array}$ & $0,5-$ & $\begin{array}{l}\text { iconographic } \\
\text { /literary } \\
\text { representatio } \\
\text { ns }\end{array}$ & $1-$ & $\begin{array}{l}\text { the use of } \\
\text { aesthetic, } \\
\text { cultural and } \\
\text { economic } \\
\text { value }\end{array}$ \\
\hline $1,5-$ & $\begin{array}{l}\text { paleogeograph } \\
\text { ic interest }\end{array}$ & $0,5-$ & $\begin{array}{l}\text { yearly } \\
\text { visitors } \\
\text { number }\end{array}$ & $3-$ & $\begin{array}{l}\text { landscape } \\
\text { framing }\end{array}$ & $2-$ & $\begin{array}{l}\text { religious } \\
\text { characteristi } \\
\text { cs }\end{array}$ & $1-$ & $\begin{array}{l}\text { vulnerabil } \\
\text { ity/natural } \\
\text { risks }\end{array}$ \\
\hline $2,5-$ & $\begin{array}{l}\text { integrity/intact } \\
\text { ness }\end{array}$ & $0,5-$ & $\begin{array}{l}\text { economic } \\
\text { potential } \\
\text { (incomes) }\end{array}$ & $2-$ & $\begin{array}{l}\text { space } \\
\text { structurin } \\
\mathrm{g}\end{array}$ & $2-$ & $\begin{array}{l}\text { historical } \\
\text { characteristi } \\
\text { cs }\end{array}$ & $0,5-$ & $\begin{array}{l}\text { relationship } \\
\text { with planning } \\
\text { policies }\end{array}$ \\
\hline 1 - & $\begin{array}{l}\text { use in } \\
\text { educational } \\
\text { purposes }\end{array}$ & & & & & $0,5-$ & $\begin{array}{l}\text { cultural } \\
\text { manifestatio } \\
\text { ns }\end{array}$ & $0,5-$ & $\begin{array}{l}\text { equipment } \\
\text { and support } \\
\text { services }\end{array}$ \\
\hline $0,5-$ & diversity & & & & & & & & \\
\hline 1 - & ecologic value & & & & & & & & \\
\hline 1 - & $\begin{array}{l}\text { representative } \\
\text { ness }\end{array}$ & & & & & & & & \\
\hline \multirow[t]{4}{*}{$0,5-$} & $\begin{array}{l}\text { other } \\
\text { geological } \\
\text { features }\end{array}$ & & & & & & & & \\
\hline & 12 & & 4 & & 16 & & 12 & & 6 \\
\hline & & & & & $50 \mathrm{pts}$ & & & & \\
\hline & & & Total value: & & 0.50 & & & & \\
\hline
\end{tabular}


Table 8. The evaluation of the geomorphosite nr. 6

\begin{tabular}{|c|c|c|c|c|c|c|c|c|c|}
\hline \multicolumn{2}{|c|}{ Scientific value } & \multicolumn{2}{|c|}{ Economic value } & \multicolumn{2}{|c|}{ Aesthetic value } & \multicolumn{2}{|c|}{ Cultural value } & \multicolumn{2}{|c|}{$\begin{array}{c}\text { Management and } \\
\text { use value }\end{array}$} \\
\hline PTS & 25 & PTS & 20 & PTS & 20 & PTS & 20 & PTS & 15 \\
\hline $0,5-$ & $\begin{array}{l}\text { rareness at } \\
\text { national level }\end{array}$ & $0,5-$ & $\begin{array}{l}\text { infrastructur } \\
\mathrm{e}\end{array}$ & 4 - & visibility & $4-$ & $\begin{array}{l}\text { symbolic } \\
\text { value }\end{array}$ & $3-$ & $\begin{array}{l}\text { preservation } \\
\text { degree }\end{array}$ \\
\hline 1 - & $\begin{array}{l}\text { rareness in } \\
\text { relation to the } \\
\text { area }\end{array}$ & $0,5-$ & accessibility & $4-$ & $\begin{array}{l}\text { color } \\
\text { contrast }\end{array}$ & $3-$ & $\begin{array}{l}\text { cultural } \\
\text { characteristi } \\
\text { cs }\end{array}$ & $1-$ & $\begin{array}{l}\text { the intensity } \\
\text { of use }\end{array}$ \\
\hline $1,5-$ & $\begin{array}{l}\text { degree of } \\
\text { scientific } \\
\text { knowledge on } \\
\text { geomorpholog } \\
\text { ical issues }\end{array}$ & $1-$ & $\begin{array}{l}\text { number of } \\
\text { types and } \\
\text { forms of use } \\
\text { (inclusively } \\
\text { touristic) }\end{array}$ & $4-$ & $\begin{array}{l}\text { level } \\
\text { difference }\end{array}$ & $0,5-$ & $\begin{array}{l}\text { iconographic } \\
\text { /literary } \\
\text { representatio } \\
\text { ns }\end{array}$ & $1-$ & $\begin{array}{l}\text { the use of } \\
\text { aesthetic, } \\
\text { cultural and } \\
\text { economic } \\
\text { value }\end{array}$ \\
\hline $2-$ & $\begin{array}{l}\text { paleogeograph } \\
\text { ic interest }\end{array}$ & $0,5-$ & $\begin{array}{l}\text { yearly } \\
\text { visitors } \\
\text { number }\end{array}$ & $4-$ & $\begin{array}{l}\text { landscape } \\
\text { framing }\end{array}$ & $1-$ & $\begin{array}{l}\text { religious } \\
\text { characteristi } \\
\text { cs }\end{array}$ & $2-$ & $\begin{array}{l}\text { vulnerabil } \\
\text { ity/natural } \\
\text { risks }\end{array}$ \\
\hline 3 - & $\begin{array}{l}\text { integrity/intact } \\
\text { ness }\end{array}$ & $0,5-$ & $\begin{array}{l}\text { economic } \\
\text { potential } \\
\text { (incomes) }\end{array}$ & 4 - & $\begin{array}{l}\text { space } \\
\text { structurin } \\
\mathrm{g}\end{array}$ & $1-$ & $\begin{array}{l}\text { historical } \\
\text { characteristi } \\
\text { cs }\end{array}$ & $0,5-$ & $\begin{array}{l}\text { relationship } \\
\text { with planning } \\
\text { policies }\end{array}$ \\
\hline 1 - & $\begin{array}{l}\text { use in } \\
\text { educational } \\
\text { purposes }\end{array}$ & & & & & $0,5-$ & $\begin{array}{l}\text { cultural } \\
\text { manifestatio } \\
\text { ns }\end{array}$ & $0,5-$ & $\begin{array}{l}\text { equipment } \\
\text { and support } \\
\text { services }\end{array}$ \\
\hline 1 - & diversity & & & & & & & & \\
\hline $5-$ & ecologic value & & & & & & & & \\
\hline $0,5-$ & $\begin{array}{l}\text { representative } \\
\text { ness }\end{array}$ & & & & & & & & \\
\hline \multirow[t]{4}{*}{$0,5-$} & $\begin{array}{l}\text { other } \\
\text { geological } \\
\text { features }\end{array}$ & & & & & & & & \\
\hline & 16 & & 3 & & 20 & & 10 & & 8 \\
\hline & & & & & $57 \mathrm{pts}$ & & & & \\
\hline & & & Total value: & & 0.57 & & & & \\
\hline
\end{tabular}

Table 9. The evaluation of the geomorphosite nr. 7

\begin{tabular}{|c|c|c|c|c|c|c|c|c|c|}
\hline \multicolumn{2}{|c|}{ Scientific value } & \multicolumn{2}{|c|}{ Economic value } & \multicolumn{2}{|c|}{ Aesthetic value } & \multicolumn{2}{|c|}{ Cultural value } & \multicolumn{2}{|c|}{$\begin{array}{c}\text { Management and } \\
\text { use value }\end{array}$} \\
\hline PTS & 25 & PTS & 20 & PTS & 20 & PTS & 20 & PTS & 15 \\
\hline $0,5-$ & $\begin{array}{l}\text { rareness at } \\
\text { national level }\end{array}$ & $2-$ & $\begin{array}{l}\text { infrastructur } \\
\mathrm{e}\end{array}$ & $4-$ & visibility & $3-$ & $\begin{array}{l}\text { symbolic } \\
\text { value }\end{array}$ & $2-$ & $\begin{array}{l}\text { preservation } \\
\text { degree }\end{array}$ \\
\hline 1 - & $\begin{array}{l}\text { rareness in } \\
\text { relation to the } \\
\text { area }\end{array}$ & $0,5-$ & accessibility & $4-$ & $\begin{array}{l}\text { color } \\
\text { contrast }\end{array}$ & $3-$ & $\begin{array}{l}\text { cultural } \\
\text { characteristi } \\
\text { cs }\end{array}$ & $2-$ & $\begin{array}{l}\text { the intensity } \\
\text { of use }\end{array}$ \\
\hline $1,5-$ & $\begin{array}{l}\text { degree of } \\
\text { scientific } \\
\text { knowledge on } \\
\text { geomorpholog } \\
\text { ical issues }\end{array}$ & $2-$ & $\begin{array}{l}\text { number of } \\
\text { types and } \\
\text { forms of use } \\
\text { (inclusively } \\
\text { touristic) }\end{array}$ & $4-$ & $\begin{array}{l}\text { level } \\
\text { difference }\end{array}$ & $0,5-$ & $\begin{array}{l}\text { iconographic } \\
\text { /literary } \\
\text { representatio } \\
\text { ns }\end{array}$ & $2-$ & $\begin{array}{l}\text { the use of } \\
\text { aesthetic, } \\
\text { cultural and } \\
\text { economic } \\
\text { value }\end{array}$ \\
\hline 2 - & $\begin{array}{l}\text { paleogeograph } \\
\text { ic interest }\end{array}$ & $0,5-$ & $\begin{array}{l}\text { yearly } \\
\text { visitors } \\
\text { number }\end{array}$ & $4-$ & $\begin{array}{l}\text { landscape } \\
\text { framing }\end{array}$ & $1-$ & $\begin{array}{l}\text { religious } \\
\text { characteristi } \\
\text { cs }\end{array}$ & 2 - & $\begin{array}{l}\text { vulnerabil } \\
\text { ity/natural } \\
\text { risks }\end{array}$ \\
\hline $2-$ & $\begin{array}{l}\text { integrity/intact } \\
\text { ness }\end{array}$ & $1-$ & $\begin{array}{l}\text { economic } \\
\text { potential } \\
\text { (incomes) }\end{array}$ & $3-$ & $\begin{array}{l}\text { space } \\
\text { structurin } \\
\mathrm{g}\end{array}$ & $1-$ & $\begin{array}{l}\text { historical } \\
\text { characteristi } \\
\text { cs }\end{array}$ & $1-$ & $\begin{array}{l}\text { relationship } \\
\text { with planning } \\
\text { policies }\end{array}$ \\
\hline 1 - & $\begin{array}{l}\text { use in } \\
\text { educational } \\
\text { purposes }\end{array}$ & & & & & $0,5-$ & $\begin{array}{l}\text { cultural } \\
\text { manifestatio } \\
\text { ns }\end{array}$ & $1-$ & $\begin{array}{l}\text { equipment } \\
\text { and support } \\
\text { services }\end{array}$ \\
\hline $1-$ & diversity & & & & & & & & \\
\hline $2-$ & ecologic value & & & & & & & & \\
\hline $0,5-$ & $\begin{array}{l}\text { representative } \\
\text { ness }\end{array}$ & & & & & & & & \\
\hline
\end{tabular}




\begin{tabular}{lllll}
\hline $\mathbf{0 , 5}$ - & $\begin{array}{l}\text { other } \\
\text { geological } \\
\text { features }\end{array}$ & & & \\
12 & 6 & 19 & 9 & 10 \\
& & $56 \mathrm{pts}$ & \\
\hline & Total value: & 0.56 & & \\
\hline
\end{tabular}

Table 10. The evaluation of the geomorphosite nr. 8

\begin{tabular}{|c|c|c|c|c|c|c|c|c|c|}
\hline \multicolumn{2}{|c|}{ Scientific value } & \multicolumn{2}{|c|}{ Economic value } & \multicolumn{2}{|c|}{ Aesthetic value } & \multicolumn{2}{|c|}{ Cultural value } & \multicolumn{2}{|c|}{$\begin{array}{c}\text { Management and } \\
\text { use value }\end{array}$} \\
\hline PTS & 25 & PTS & 20 & PTS & 20 & PTS & 20 & PTS & 15 \\
\hline 1 - & $\begin{array}{l}\text { rareness at } \\
\text { national level }\end{array}$ & $2-$ & $\begin{array}{l}\text { infrastructur } \\
\mathrm{e}\end{array}$ & $3-$ & visibility & $2-$ & $\begin{array}{l}\text { symbolic } \\
\text { value }\end{array}$ & $2,5-$ & $\begin{array}{l}\text { preservation } \\
\text { degree }\end{array}$ \\
\hline $1,5-$ & $\begin{array}{l}\text { rareness in } \\
\text { relation to the } \\
\text { area }\end{array}$ & $3-$ & accessibility & $3-$ & $\begin{array}{l}\text { color } \\
\text { contrast }\end{array}$ & $4-$ & $\begin{array}{l}\text { cultural } \\
\text { characteristi } \\
\text { cs }\end{array}$ & $1-$ & $\begin{array}{l}\text { the intensity } \\
\text { of use }\end{array}$ \\
\hline 3 - & $\begin{array}{l}\text { degree of } \\
\text { scientific } \\
\text { knowledge on } \\
\text { geomorpholog } \\
\text { ical issues }\end{array}$ & $2-$ & $\begin{array}{l}\text { number of } \\
\text { types and } \\
\text { forms of use } \\
\text { (inclusively } \\
\text { touristic) }\end{array}$ & $3-$ & $\begin{array}{l}\text { level } \\
\text { difference }\end{array}$ & $0,5-$ & $\begin{array}{l}\text { iconographic } \\
\text { /literary } \\
\text { representatio } \\
\text { ns }\end{array}$ & $1-$ & $\begin{array}{l}\text { the use of } \\
\text { aesthetic, } \\
\text { cultural and } \\
\text { economic } \\
\text { value }\end{array}$ \\
\hline 3 - & $\begin{array}{l}\text { paleogeograph } \\
\text { ic interest }\end{array}$ & $1,5-$ & $\begin{array}{l}\text { yearly } \\
\text { visitors } \\
\text { number }\end{array}$ & $3-$ & $\begin{array}{l}\text { landscape } \\
\text { framing }\end{array}$ & 2 - & $\begin{array}{l}\text { religious } \\
\text { characteristi } \\
\text { cs }\end{array}$ & $1-$ & $\begin{array}{l}\text { vulnerabil } \\
\text { ity/natural } \\
\text { risks }\end{array}$ \\
\hline $2,5-$ & $\begin{array}{l}\text { integrity/intact } \\
\text { ness }\end{array}$ & $1,5-$ & $\begin{array}{l}\text { economic } \\
\text { potential } \\
\text { (incomes) }\end{array}$ & $2-$ & $\begin{array}{l}\text { space } \\
\text { structurin } \\
\mathrm{g}\end{array}$ & $2-$ & $\begin{array}{l}\text { historical } \\
\text { characteristi } \\
\text { cs }\end{array}$ & $0,5-$ & $\begin{array}{l}\text { relationship } \\
\text { with planning } \\
\text { policies }\end{array}$ \\
\hline 2 - & $\begin{array}{l}\text { use in } \\
\text { educational } \\
\text { purposes }\end{array}$ & & & & & $0,5-$ & $\begin{array}{l}\text { cultural } \\
\text { manifestatio } \\
\text { ns }\end{array}$ & $1-$ & $\begin{array}{l}\text { equipment } \\
\text { and support } \\
\text { services }\end{array}$ \\
\hline $2-$ & diversity & & & & & & & & \\
\hline 3 - & ecologic value & & & & & & & & \\
\hline 2 - & $\begin{array}{l}\text { representative } \\
\text { ness }\end{array}$ & & & & & & & & \\
\hline
\end{tabular}

Table 11. The geomorphosites ranking

\begin{tabular}{lccccccccc}
\hline Nr. & Name & $\begin{array}{c}\text { Scientific } \\
\text { value }\end{array}$ & $\begin{array}{c}\text { Economic } \\
\text { value }\end{array}$ & $\begin{array}{c}\text { Aesthetic } \\
\text { value }\end{array}$ & $\begin{array}{c}\text { Cultural } \\
\text { value }\end{array}$ & $\begin{array}{c}\text { M } \\
\text { \& } \\
\text { U }\end{array}$ & $\begin{array}{c}\text { Tot. } \\
\text { pts. }\end{array}$ & $\begin{array}{c}\text { Ev. } \\
\text { score }\end{array}$ & Rank \\
\hline 1. & Cheile Tișiței & 23 & 11 & 17 & 11 & 10 & 72 & 0.72 & 2 \\
\hline 2. & Cascada Putnei & 23 & 15 & 16 & 12 & 11 & 77 & 0.77 & 1 \\
\hline 3. & Groapa cu Pini & 21 & 6 & 15 & 13 & 7 & 62 & 0.62 & 4 \\
\hline 4. & Strâmtura Coza & 19 & 6 & 15 & 11 & 7 & 58 & 0.58 & 5 \\
\hline 5. & Cascada din Horn & 12 & 4 & 16 & 12 & 6 & 50 & 0.50 & 8 \\
\hline 6. & Varful Goru & 16 & 3 & 20 & 10 & 8 & 57 & 0.57 & 6 \\
\hline 7. & Vârful Lăcăuți & 12 & 6 & 19 & 9 & 10 & 56 & 0.56 & 7 \\
\hline 8. & Râpa Roșie & 21 & 10 & 14 & 11 & 7 & 63 & 0.63 & 3 \\
\hline
\end{tabular}




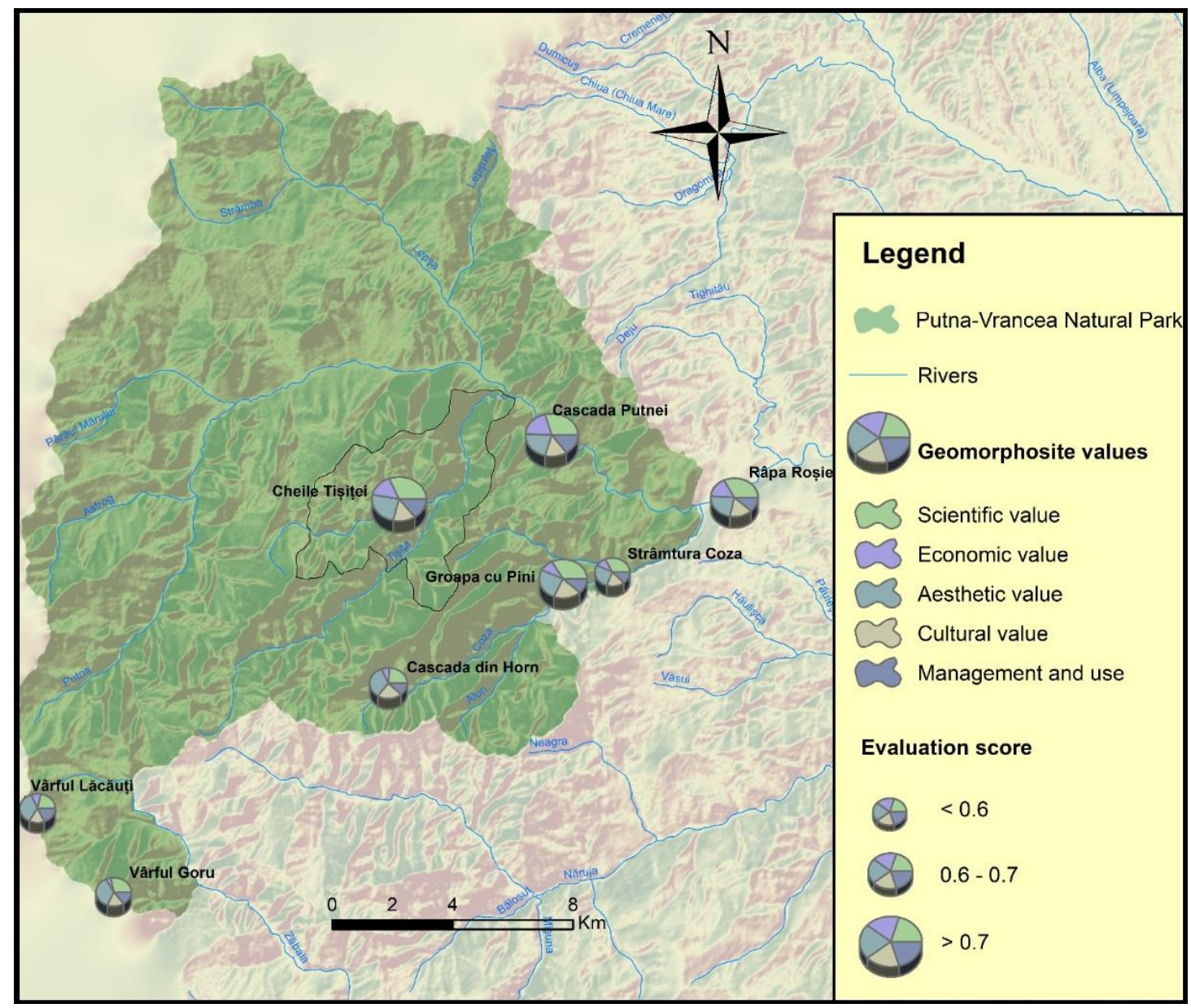

Figure 4 The evaluation of the geomorphosites

As a result of the assessment, the maximum value was 0.77 and was obtained by the geomorphosite with the number 2 (Cascada Putnei) and the minimum value was recorded by the geomorphosite with the number 5 (Cascada din Horn), which obtained the total value of 0.5 .

\section{CONCLUSIONS}

It can be observed that the aesthetic value registered high values for all the analyzed geomorphosites, an important aspect for the eventuality of the tourist exploitation of these objectives. With a few exceptions, the scientific value represented a large part of the total value of the geomorphosites, which indicate their great importance from a scientific point of view. Regarding the cultural value, also an important aspect for the eventual tourist utility, it matters a lot that the area analyzed is under the influence of the cultural region known as the "Tara Vrancei".

It should be noted, that most of the geomorphosites have obtained low scores for the economic value, mostly due to the lack of infrastructure and poor accessibility, but also for the management and use value.

Given that the analyzed geomorphosites are part of a protected area (some of them even have the status of independent nature reserves), they enjoy a favorable legislative framework, which positively influences their degree of protection. 
Thus, following the assessment of the geomorphosites from the Putna-Vrancea Natural Park, we can say that the analyzed area possesses an important geotouristic heritage that is not exploited to its true value, in this way, being necessary investments in infrastructure, but also an efficiency of the current promotion modalities. .

The proposed evaluation method was applied in Putna-Vrancea Natural Park in order to highlight the geotouristic value of the geomorphosites in this area, as well as to obtain a basis for rethinking the protection measures and promoting geotourism at the region level. Also, the proposed methodology together with other established methodologies [24], [25], [26] can contribute to the improvement of the management plans regarding the efficient exploitation of the local economic resources (implicitly the tourist ones).

\section{Acknowledgement}

This paper is co-financed from the Human Capital Operational Program 2014-2020, project number POCU / 380/6/13/125245 no. 36482 / 23.05.2019 "Excellence in interdisciplinary $\mathrm{PhD}$ and post- $\mathrm{PhD}$ research, career alternatives through entrepreneurial initiative (EXCIA)", coordinator The Bucharest University of Economic Studies".

\section{REFERENCES}

[1] Stoffelen A. \& Vanneste D., An integrative geotourism approach: bridging conflicts in tourism landscape research. Tour. Geogr. 17 (4), pp. 544-560, 2015.

[2] Garofano M., Challenges in the Popularization of the Earth Sciences. Geotourism as a New Medium for the Geology Dissemination. Anuario do Instituto de Geociencias-UFRJ, 35 (1), pp. 34-41, 2012.

[3] Hose T.A., Selling the story of Brain's stone. Environ. Interpret. 10 (2), pp. 16-17, 1995.

[4] Comănescu L. \& Nedelea A., Analysis of some representative geomorphosites in the Bucegi Mountains: between scientific evaluation and tourist perception. Area 4, pp. 406-416, 2010.

[5] Yolal M., Geotourism and geoparks: the case of Kizilcahamam-Çamlidere Geopark, GeoJournal of Tourism and Geosites Year V no.2, vol. 10, pp. 193-203, 2012.

[6] Dowling R.K., 2015, Geotourism. In: Cater, C., Garrod, B., Low, T. (Eds.), The Encyclopedia of Sustainable Tourism. CABI, Oxford, pp. 231-232, 2015.

[7] Necheș I.M. \& Erdeli G., Geolandscapes and geotourism: integrating nature and culture in the Bucegi Mountains of Romania. Lands. Res. 40 (4), pp. 486-509, 2015.

[8] Panizza M., Geomorphosites: concepts, methods and example of geomorphological survey. Chinese Science Bulletin 46, Supplement 1:4-5, 2001.

[9] Panizza M. \& Piacente S., Geomorfologia culturale, Pitagora Editrice, Bologna, 2003.

[10] Reynard E., Geomorphosites et paysages, Geomorphologie: relief, processus, environnement, 3, pp. 181-188, 2005.

[11] Grandgirard V., L'evaluation des geotopes, Geologia Insubrica 4-1, pp. 59-66, 1999.

[12] Reynard E. \& Panizza M., Geomophosites: definition, assessment and mapping. An introduction, Geomorphologie: relief, processus, environnement, 3, pp. 177-180, 2005.

[13] Pralong J.P., A method for assessing tourist potential and use of geomorphological sites, Geomorphologie: relief, processus, environnement, nr. 3/2005, pp. 189-196, 2005.

[14] Reynard E., Fontana G., Kozlik L. \& Scapozza C., A method for assessing „scientific” and „additional values” of geomorphosites, Geographica Helvetica, 62, 3, pp. 148-158, 2007.

[15] Bruschi V.M. \& Cendrero A., Geosite evaluation; can we measure intangible values? Il Quaternario 18(1), pp. 293-306, 2005. 
[16] Coratza P. \& Giusti C., Methodological proposal for the assessment of the scientific quality of geomorphosites, Il Quaternario, 18(1), pp. 307-313, 2005.

[17] Serrano E. \& Gonzalez-Trueba J.J., Assessment of geomorphosites in natural protected areas: the Picos de Europa National Park (Spain), Geomorphologie: relief, processus, environnement, nr. 3/2005, pp. 197-208, 2005.

[18] Pereira P., Pereira D. \& Caetano Alves M. I., Geomorphosite assessment in Montesinho Natural Park (Portugal), Geographica Helvetica, 62 (3), pp. 159-169, 2007.

[19] Zouros N., Assessment, protection and promotion of geomorphological and geological sites in the Aegean area, Greece, Geomorphologie: relief, processus, environnement, 3, pp. 227-234, 2005.

[20] Erhatic B., Geomorphosite assessment. Acta geographica Slovenica, 50-2, pp. 296-309, 2010.

[21] Comănescu L., Nedelea A. \& Dobre R., The Evaluation of Geomorphosites from the Ponoare Protected Area, Forum Geografic, Studii și cercetări de geografie și protecția mediului, Vol. 11, pp. 54-61, 2011.

[22] Chiriac S., Sandu R.M., Militaru I., Ciurescu S., Ioja I.C., Rozylowicz L. \& Negulescu, D., The Putna-Vrancea Natural Park Management Plan, Conservation of large carnivore in Vrancea County, 2005.

[23] Roman, F., Munții Vrancei. Ghid turistic, Editura Sport-Turism, București, 1989.

[24] Pintilii R.D., Andronache I., Diaconu D.C., Dobrea R.C., Zelenakova M., Fensholt R., Peptenatu D., Draghici C.C. \& Ciobotaru A.M. Using Fractal Analysis in Modeling the Dynamics of Forest Areas and Economic Impact Assessment: Maramures County, Romania, as a Case Study, Forests, vol. 8, 2017.

[25] Drăghici C.C., Andronache I., Ahammer H., Peptenatu D., Pintilii R.D., Ciobotaru A.M., Simion A.G., Dobrea R.C., Diaconu D.C., Vișan M.C. \& Papuc R.M. Spatial evolution of forest areas in the northern Carpathian Mountains of Romania, Acta Montanistica Slovaca, vol. 22, pp 95-106, 2017.

[26] Popa, M.C., Peptenatu, D., Drăghici, C.C., \& Diaconu, D.C. Flood Hazard Mapping Using the Flood and Flash-Flood Potential Index in the Buzău River Catchment, Romania, Water, 11, 2116, 2019. 